\title{
DETERMINATION OF INERT CHEMICAL OXYGEN DEMAND (COD) FRACTIONS OF CUMHURIYET UNIVERSITY WASTEWATER
}

\section{F. CINER* \\ M. SARIOGLU}

\author{
Cumhuriyet University, Engineering Faculty \\ Department of Environ. Eng. \\ 58140, Sivas, Turkey
}

*to whom all correspondence should be addressed
e-mail: fciner@cumhuriyet.edu.tr

*to whom all correspondence should be addressed
e-mail: $\underline{\text { fciner@ } @ \text { cumhuriyet.edu.tr }}$

\author{
Selected from papers presented in $9^{\text {th }}$ \\ International Conference on Environmental \\ Science and Technology (9CEST2005) \\ 1-3 September 2005, Rhodes island, Greece
}

\begin{abstract}
Some amounts of inert products are given into environment due to biological degradation of substrate in activated sludge system. The effluent of biological wastewater treatment consists of inert substrate in influent flow, soluble microbial products and non degradable or slowly degradable organic products.
\end{abstract}

Soluble inert COD $\left(S_{\mathrm{l}}\right)$ must be determined for discharge standards since it did not give any reaction in activated sludge system and was given with wastewater discharge. However particular inert COD $\left(X_{1}\right)$ accumulated in system depending on sludge retention time due to it is only wasted from system by wasted sludge.

This study focused on inert fractions of Cumhuriyet University campus wastewater which consists of domestic, hospital and laboratory wastewaters. Experimental method was used suggested by Orhon et al. and modified by Germirli et al. in order to determine directly influent particulate and soluble inert fractions. According to the experimental procedure three aerobic batch reactors, two with the wastewater and the third with glucose were run parallel. In the reactors, the change in the soluble COD profiles is observed for a period during which all degradable COD is entirely depleted, in other words, the COD profiles reach a plateau and remain unchanged.

Wastewater samples were taken equalization tank in wastewater treatment plant. The conventional parameters of campus wastewater characterization were as follows: Total COD $\left(C_{\text {TO }}\right)=372 \mathrm{mg} \mathrm{l}^{-1}$, total soluble $\mathrm{COD}\left(\mathrm{S}_{\mathrm{TO}}\right)=124 \mathrm{mg} \mathrm{l}^{-1}$, total suspended solids $(\mathrm{TSS})=177$ $\mathrm{mg} \mathrm{l}^{-1}$, ammonia $\left(\mathrm{NH}_{3}\right)=31.2 \mathrm{mg} \mathrm{l}^{-1}$, ortho-phosphate $\left(\mathrm{PO}_{4}-\mathrm{P}\right)=11.3 \mathrm{mg} \mathrm{l}^{-1}$ and $\mathrm{pH}=7,4$.

In this study, in order to determine inert COD fractions in Cumhuriyet University campus wastewater, three aerobic batch reactor systems were used. At the end of approximately 381 $\mathrm{h}$ operation, COD composition of campus wastewater were found to be $\mathrm{C}_{\mathrm{TO}}=372 \mathrm{mg} \mathrm{I}^{-1}$, $\mathrm{X}_{\mathrm{S} 0}=56 \mathrm{mg} \mathrm{l}^{-1}, \mathrm{~S}_{\mathrm{S} 0}=104 \mathrm{mg} \mathrm{l}^{-1}, \mathrm{C}_{\mathrm{S} 0}=149 \mathrm{mg} \mathrm{l}^{-1}, \mathrm{~S}_{\mathrm{I}}=12 \mathrm{mg} \mathrm{l}^{-1}, \mathrm{X}_{\mathrm{l}}=211 \mathrm{mg} \mathrm{l}^{-1}$, respectively.

KEYWORDS: Activated sludge, glucose, inert COD components, residual metabolic products, campus wastewater, Sivas.

\section{INTRODUCTION}

One of the biological wastewater systems, activated sludge process, is widely used. The modelling and design of these systems are essential aspect of Environmental Engineering [1]. Conventional activated sludge models composed of single substrate and biomass components are useless in last days. Multicomponent models are chosen for both characterization of raw wastewater and explanation and understanding of activated sludge process [2]. Up to now, activated sludge models used assumed that effluent substrate concentration was independent of influent substrate concentration and substrate 
characterization of effluent and influent remained unchanged. A lot of research indicated that most of the residual substrate were produced by biomass and effluent substrate concentration related with influent of it. Both influent and effluent substrate components and components of biomass can be determined by using multicomponent activated sludge models recently $[2,3]$.

The important point on multicomponent models of activated sludge systems is determination of wastewater characterization. This depends on organic matter and characterization of wastewater. COD parameter used for substrate determination can not give degradation of organic matter biologically. Therefore, biological degradation parts and inert fraction of COD must be determined since all modelling and calculations of design need to do with biodegradable COD. The determination of particulate and inert fractions of wastewaters are also important in order to regulate the discharge standards and operating conditions [1].

Inert COD parameters considered in modelling and design of activated sludge systems are only not inert COD components in wastewater. It must be also determined the soluble $\left(S_{P}\right)$ and particulate microbial $\left(X_{P}\right)$ products occured with biological growth processes[1]. Inert soluble $\operatorname{COD}\left(S_{1}\right)$ and inert particulate $\operatorname{COD}\left(X_{1}\right)$ leave the treatment system unchanged, however, $X_{1}$ is entrapped in the sludge line[4]. Both $S_{1}$ and $X_{1}$ inert COD components in wastewaters and also soluble and particulate inert metabolic products occurred in system must be determined in order to assess suitable operation conditions with providing correct modelling and design [1].

In this study, soluble and particulate inert COD fractions in wastewater of Cumhuriyet University and residual soluble inert metabolic products come from biological growth processes were experimentally investigated. Three aerobic batch reactors were used in order to determine inert COD fractions in wastewater composed of hospital, laboratory and domestic wastewaters. Inert COD parameters were observed from batch reactors acclimated with wastewater and glucose and fed with raw, filtrated wastewater and glucose throughout 381 hours.

\section{CONCEPTUAL APPROACH}

Effluent total soluble COD $\left(\mathrm{S}_{\mathrm{T}}\right)$ includes non-biodegradable organics from wastewater and same in influent and effluent $\left(S_{1}\right)$, some part of biological degradable amount COD $\left(S_{S}+S_{H}\right)$ from residual biological oxidation and soluble inert $\operatorname{COD}\left(\mathrm{S}_{\mathrm{P}}\right)$ produced as metabolic product. As a result, effluent generally includes more soluble inert COD than wastewater, since effluent soluble inert COD includes various soluble inert products except soluble inert COD of wastewater unchanged in reactor $\left(S_{R}\right)[5]$.

Experimental method was used suggested by Orhon et al. (1994) and modified by Germirli et al. (1991) in order to determine directly influent particulate and soluble inert fractions. This method involves running three batch reactors, two with the wastewater to be studied and the third with glucose. One of the wastewater reactors with the total COD $\left(\mathrm{C}_{\mathrm{TO}}\right)$, and the second with the total soluble $\operatorname{COD}\left(\mathrm{S}_{\mathrm{TO}}\right)$ and, whereas the initial $\mathrm{COD}$ in the glucose reactor is adjusted to equal $\mathrm{S}_{\text {TO. }}$. The experimental studies are performed until all the biodegradable COD is depleted, where the COD profiles reach a plateau and stay unchanged. As shown in Figure 1 , soluble COD in glucose reactor reaches $S_{P G}$ value, as glucose contains no initially inert fraction, being a soluble compound. Total of $S_{1}$ and $S_{P 1}$ reaches $S_{R 1}$ values beginning with $S_{\text {TO }}$ value. Therefore, $S_{\text {I }}$ value can be calculated as follows [6]:

$\mathrm{S}_{\mathrm{I}}=\mathrm{S}_{\mathrm{R} 1}-\mathrm{S}_{\mathrm{PG}}$

Where, two reactor are operated with approximately the same $\mathrm{S}_{\mathrm{SO}}$. It is assumed as,

$\left(\mathrm{S}_{\mathrm{P}}\right)_{\text {wastewater }} \approx\left(\mathrm{S}_{\mathrm{P}}\right)_{\text {glucose }}$

$Y_{1}$ coefficient can be written by using $S_{\text {I }}$ and $S_{T O}$.

$Y_{1}=\frac{S_{1}}{S_{S 0}}$

$\mathrm{Y}_{\mathrm{SP}}$ stoichiometric coefficient can be formulated with following equation, 
$\mathrm{Y}_{\mathrm{SP}}=\frac{\mathrm{S}_{\mathrm{R} 1}-\mathrm{S}_{1}}{\mathrm{~S}_{\mathrm{T} 0}-\mathrm{S}_{1}}=\frac{\mathrm{S}_{\mathrm{P} 1}}{\mathrm{~S}_{\mathrm{S} 0}}$

First reactor fed with degradable soluble and particulate fractions $\left(\mathrm{C}_{\mathrm{SO}}\right)$ will give high inert soluble COD, $S_{R 2}$ because of high $S_{P 2}$. Since $S_{1}$ is known, the following equations can be written,

$\mathrm{S}_{\mathrm{P} 2}=\mathrm{S}_{\mathrm{R} 2}-\mathrm{S}_{1}$

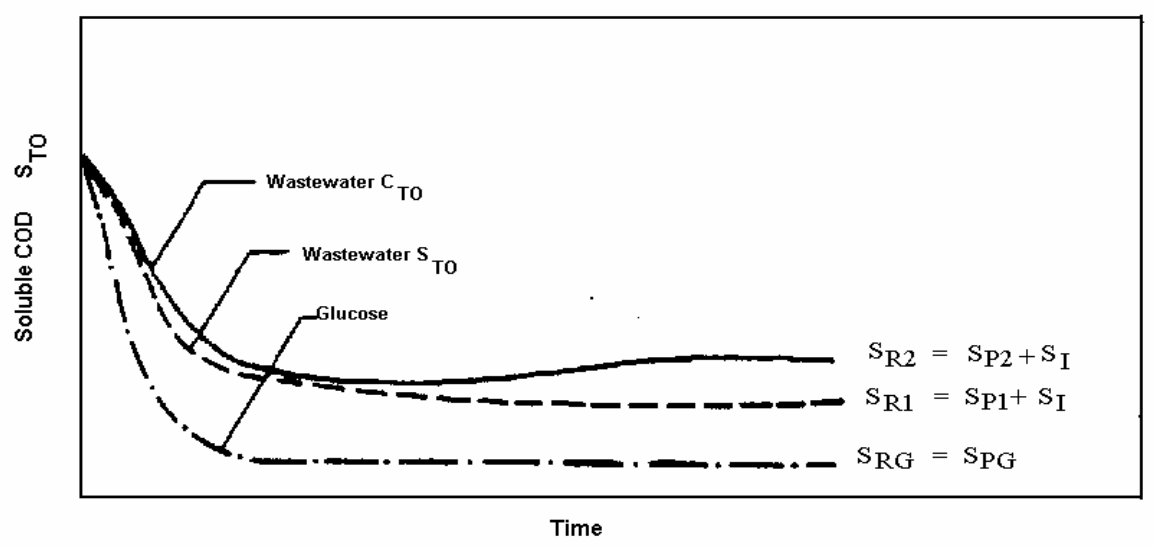

Figure 1. Experimental evaluation of $\mathrm{X}_{1}[6,8]$

$\mathrm{C}_{\mathrm{S} 0}=\frac{\mathrm{S}_{\mathrm{P} 2}}{\mathrm{~S}_{\mathrm{P} 1}} \mathrm{~S}_{\mathrm{S} 0}$

and

$\mathrm{X}_{\mathrm{I}}=\mathrm{C}_{\mathrm{T} 0}-\mathrm{C}_{\mathrm{S} 0}-\mathrm{S}_{\mathrm{I}}$

calculated.

\section{MATERIALS AND METHODS}

\subsection{Characterization of the wastewater}

In this study, Cumhuriyet University wastewater treatment plant mixture of domestic, comes from faculties in campus dormitory and houses, and hospital and laboratory wastewaters, toxic and harmful, were used. Generally campus wastewaters have different properties than domestic wastewaters considering amount and features of them, since population of campus have various regional differences. While population and average flowrate of campus during the education period were determined as 22435 and $21.48 \mathrm{I} \mathrm{s}^{-1}$, that of campus during the vacation period were found to be 7240 and $14.48 \mathrm{I} \mathrm{s}^{-1}$, respectively in 2003 by Değirmenci et al.(2004). As shown in Figure 2 wastewater samples were taken from effluent of equalization tank in Cumhuriyet University Wastewater Treatment Plants.

\subsection{Experimental study}

Three batch aerobic reactors were experimentally studied in order to determine inert COD fractions based on suggested method by Germirli et al. (1991) and Orhon et al. (1994). First, second and third reactors were fed with unfiltrated wastewater, filtrated wastewater and glucose including same COD of filtrated wastewater, respectively. All reactors were initially seeded with minimum amount of biomass concentrations (30-40 mg VSS/l) acclimated to a $50 \%$ wastewater $+50 \%$ glucose mixture. Necessary nutrients were provided by using $A$ and $B$ solutions. Enough air was given into reactors thorough the experiments. Aliquots were removed periodically from the mixed liquor and analyzed for soluble (filtrated) COD. Data were collected until the COD profiles reached a plateau.

Any water loss from the reactors by evaporation was replaced by adding distilled water before measuring COD. All experiments were conducted at room temperature and $\mathrm{pH}$ of 7,0-8,0. 


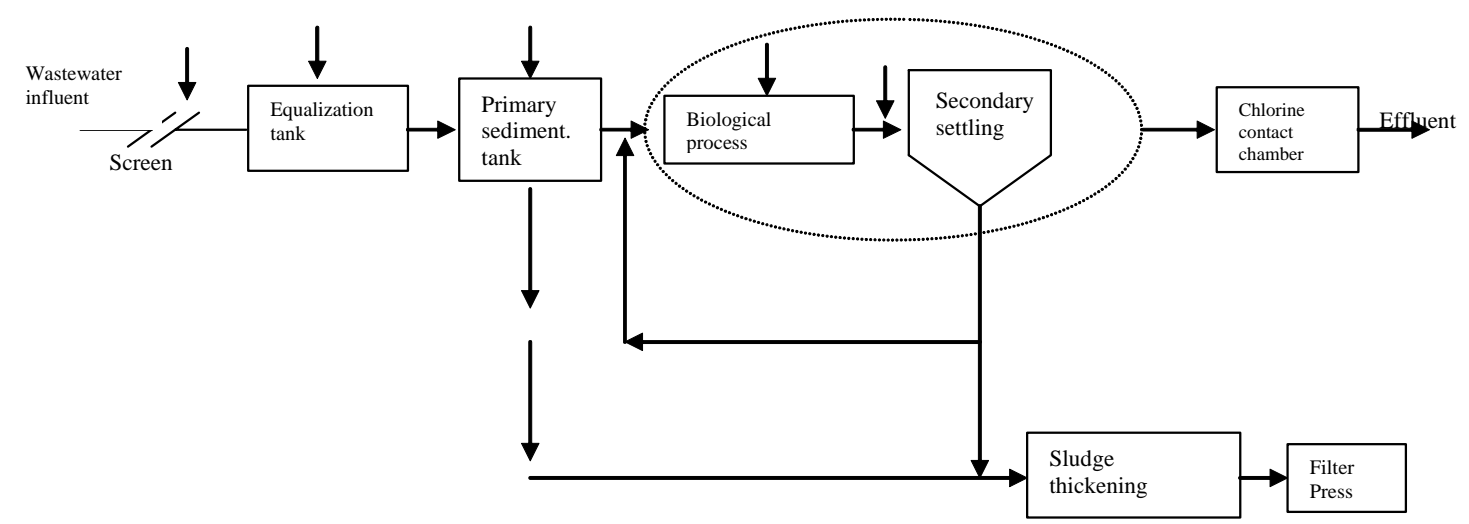

Figure 2. Illustration of Cumhuriyet University Campus Wastewater Treatment Plants

\subsection{Analytical methods}

All chemical analysis were performed in accordance with Standard Methods [10]. Both suspended solids (SS) and soluble COD fraction were measured using Millipore AP40 filter paper.

\section{RESULTS}

In this study, effluent of equalization tank in Cumhuriyet University Campus Wastewater Treatment Plants was used (Figure 2). Characterization of wastewater used in experimental study is given in Table 1.

Table 1. Properties of wastewater used in experimental study

\begin{tabular}{lc}
\hline Parameter & Concentration $\left(\mathrm{mg} \mathrm{l}^{-1}\right)$ \\
\hline $\mathrm{KOI}_{\text {total }}$ & 372 \\
$\mathrm{KOI}_{\text {soluble }}$ & 124 \\
$\mathrm{BOI}_{5}$ & 178 \\
$\mathrm{SS}$ & 177 \\
$\mathrm{PO}_{4}-\mathrm{P}$ & 11.3 \\
$\mathrm{NH}_{3}$ & 31.2 \\
$\mathrm{pH}^{*}$ & 7.4 \\
\hline
\end{tabular}

${ }^{*} \mathrm{pH}$ unit

Table 2 and Table 3 give results of inert COD determination experiments for three batch reactors and COD composition of wastewater, respectively. Determination of $X_{1}$ for the campus wastewater is shown in Fig 3.

\section{EVALUATION OF RESULTS AND CONCLUSIONS}

In this study, in order to determine soluble and particulate inert fractions of wastewaters and soluble metabolic products produced in system, batch experimental study was carried out. This study is important for modelling, design and operation of activated sludge systems and determination of discharge limits.

Experimental study conducted on three parallel batch reactors operated with wastewater sample for 381 hours until it stabilized COD levels. Experimental data were first evaluated according to equation 1 , yielding $S_{1}=12 \mathrm{mg} \mathrm{l}^{-1}$ and $S_{P_{1}}=13 \mathrm{mg} \mathrm{l}^{-1}$ with corresponding coefficients of $Y_{1}=0.115$ and $Y_{P S}=0.125$. Subsequently, $S_{P 2}, C_{S 0}$ and $X_{1}$ were found to be 20 $\mathrm{mg} \mathrm{l}^{-1}, 160 \mathrm{mg} \mathrm{l}^{-1}$ and $200 \mathrm{mg} \mathrm{l}^{-1}$ respectively by using equations 3,4 and 5 .

With the experimental assessment of $X_{1}$ and $S_{1}$, the following initial composition of wastewater sample was determined: $\mathrm{C}_{\mathrm{T} 0}=372 \mathrm{mg} \mathrm{l}^{-1}, \mathrm{X}_{\mathrm{I}}=200 \mathrm{mg} \mathrm{l}^{-1}, \mathrm{~S}_{\mathrm{I}}=12 \mathrm{mg} \mathrm{l}^{-1}, \mathrm{C}_{\mathrm{S} 0}=160 \mathrm{mg} \mathrm{l}^{-1}$ 
Table 2. Results of the inert COD determination experiments performed on raw, filtered wastewater and glucose

\begin{tabular}{|l|c|c|c|}
\hline & $\begin{array}{c}\text { Reactor I fed with } \\
\text { unfiltered wastewater } \\
\text { Soluble COD } \\
\left(\mathrm{mg} \mathrm{l}^{-1}\right)\end{array}$ & $\begin{array}{c}\text { Reactor II fed with } \\
\text { filtered wastewater } \\
\text { Soluble COD } \\
\left(\mathrm{mg} \mathrm{I}^{-1}\right)\end{array}$ & $\begin{array}{c}\text { Reactor III fed with } \\
\text { glucose } \\
\text { Soluble COD } \\
\left(\mathrm{mg} \mathrm{I}^{-1}\right)\end{array}$ \\
\hline Start of the experiment & $116\left(\mathrm{~S}_{\mathrm{TO}}\right)$ & 114 & 114 \\
\hline End of the experiment & $32\left(\mathrm{~S}_{\mathrm{R} 2}\right)$ & $25\left(\mathrm{~S}_{\mathrm{R} 1}\right)$ & $13\left(\mathrm{~S}_{\mathrm{RG}}\right)$ \\
\hline Duration (hours) & 381 & 381 & 381 \\
\hline & \multicolumn{3}{|r}{} \\
\hline
\end{tabular}

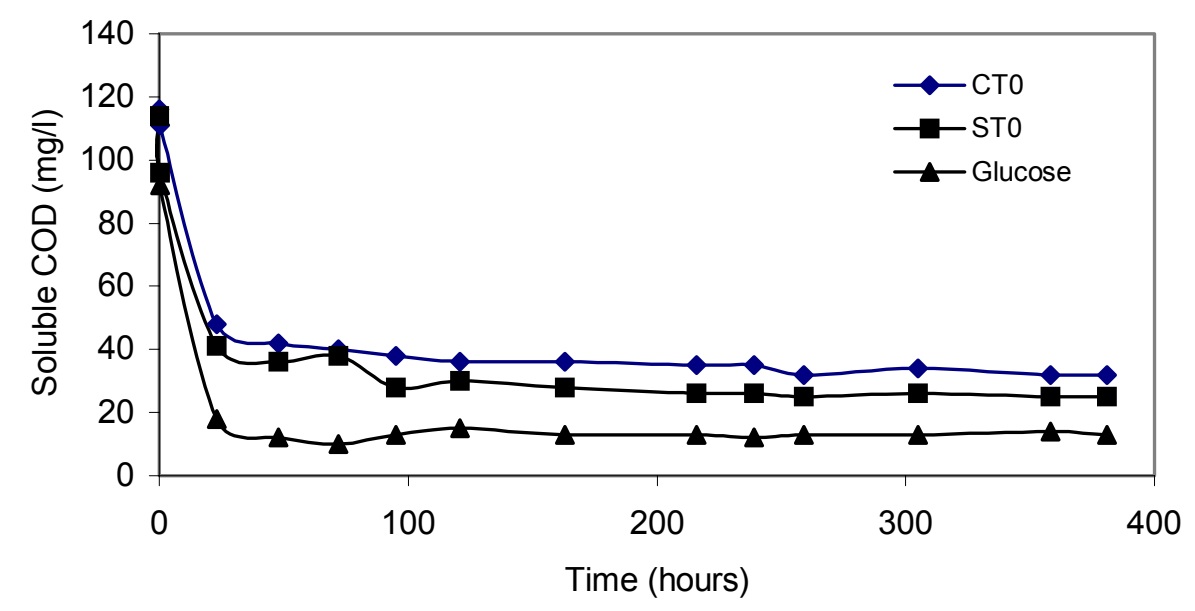

Figure 3. Determination of $X_{1}$ for the campus wastewater

Table 3. COD composition of campus wastewater determined in this study

\begin{tabular}{|c|c|}
\hline Parameter & Campus wastewater sample \\
\hline Total COD, $\mathrm{C}_{\mathrm{T} 0}\left(\mathrm{mg} \mathrm{I}^{-1}\right)$ & 372.0 \\
\hline Soluble COD, $\mathrm{S}_{\text {T0 }}\left(\mathrm{mg} \mathrm{l}^{-1}\right)$ & 116.0 \\
\hline $\mathrm{S}_{\mathrm{T} 0} / \mathrm{C}_{\mathrm{T} 0}(\%)$ & 31.2 \\
\hline Particulate fraction, $\mathrm{X}_{\mathrm{T} 0}\left(\mathrm{mg} \mathrm{l}^{-1}\right)$ & 256.0 \\
\hline $\mathrm{X}_{\mathrm{T} /} / \mathrm{C}_{\mathrm{T} 0}(\%)$ & 68.8 \\
\hline İnert COD & 212.0 \\
\hline Soluble fraction, $S_{\mid}\left(\mathrm{mg} \mathrm{l}^{-1}\right)$ & 12.0 \\
\hline $\mathrm{S}_{\mathrm{I}} / \mathrm{C}_{\mathrm{T} 0}(\%)$ & 3.2 \\
\hline Particulate fraction, $X_{I}\left(\mathrm{mg} \mathrm{l}^{-1}\right)$ & 200.0 \\
\hline $\mathrm{X}_{\mathrm{I}} / \mathrm{C}_{\mathrm{T} 0}(\%)$ & 53.8 \\
\hline Degradable COD, $\mathrm{C}_{\mathrm{SO}}\left(\mathrm{mg} \mathrm{l}^{-1}\right)$ & 160.0 \\
\hline Soluble fraction, $\mathrm{S}_{\mathrm{S} 0}\left(\mathrm{mg} \mathrm{l}^{-1}\right)$ & 104.0 \\
\hline $\mathrm{S}_{\mathrm{SO}} / \mathrm{C}_{\mathrm{T} 0}(\%)$ & 27.9 \\
\hline Particulate fraction, $\mathrm{X}_{\mathrm{so}}\left(\mathrm{mg} \mathrm{l}^{-1}\right)$ & 56.0 \\
\hline $\mathrm{X}_{\mathrm{SO}} / \mathrm{C}_{\mathrm{TO}}(\%)$ & 15.1 \\
\hline
\end{tabular}

The comparison of this composition with similar typical values shows a very good agreement for $S_{1}$, with the 25-40 mg l-1 range described in the literature corresponding to $S_{1}+S_{P_{2}}=32 \mathrm{mg} \mathrm{I}^{-}$ ${ }^{1}$ in the present study. The $X_{1}$ concentration of $200 \mathrm{mg} \mathrm{I}^{-1}$ is relatively high compared with the range in the literature $25-100 \mathrm{mg} \mathrm{l}^{-1} .78 \%$ particulate COD in influent is inert. This is attributed to the fact that except domestic wastewater both hospital and laboratory wastewaters are given into wastewater treatment systems and there is no grit chamber before biological treatment unit. 
Evaluation of experimental study indicated that $31.2 \%$ and $68.8 \%$ of total COD were soluble and particulate compounds. $27.9 \%, 3.2 \%$ and $53.8 \%$ of total COD were soluble easy degradable organic material, soluble inert and particulate inert material, respectively.

This experimental study showed that inert COD amount of wastewaters changed depending on characterization of wastewater. Therefore, they must be experimentally determined.

\section{REFERENCES}

1. Orhon D. and Karahan Ö. (1999) Assessment of Inert COD Fractions in Activated Sludge Systems, Journal of Water Pollution Control, 9, 2, 47-52.(in Turkish)

2. Ubay Çokgör E., Orhon D. and Sözen S. (1999) COD Fractionation on Domestic and Industrial Wastewaters, Journal of Water Pollution Control, 9, 2, 31-39.(in Turkish)

3. Çiner F. (1999) Modelling of Biological residual Microbial Product Formation in Activated Sludge Systems in Series With Recycle, Istanbul Tech. Unv., Ph.D. Thesis. (in Turkish)

4. Germirli F., Orhon D. Artan N., Ubay E. and Gorgun E. (1993) Effect of Two-Stage Biological Treatability of Strong Industrial Wastes, Wat. Sci. Tech., 28, 2, 145-154.

5. Orhon D. and Ubay Cokgor E. (1997) COD Fractionation in Wastewater Characterization-The State of the Art, J.Chem.Tech.Biotechnol., 68, 283-293.

6. Orhon D., Artan N. and Ateş E. (1994) A Description of Three Methods for the Determination of the Initial Inert Particulate Chemical Oxygen Demand of Wastewater, J.Chem.Tech.Biotechnol., 61, 73-80.

7. Germirli F., Orhon D. and Artan N. (1991) Assesment of the Initial Inert Soluble COD in Industrial Watewater, Wat. Sci.Tech., 23, 1077-1086.

8. Orhon D., Artan N., Büyükmurat S. and Görgün E. (1992) The Effect of Residual COD on the Biological Treatability of Textile Wastewaters, Wat. Sci. Tech., 26, 3-4, 815-825.

9. Değirmenci M., Alay S. and Altın A. (2004) General Characteristics of Campus Wastewater and Present State of Treatment Plant in Cumhuriyet University, Proceedings from Cumhuriyet Unv., Environment 2004 Symposium,497-505.(in Turkish)

10. APHA/AWWA/WPCF (1998) Standart Methods For The Examination Of Water And Wastewater, $20^{\text {th }}$ Edition, American Public Health Association, Washington DC. 